\title{
Self-Regulatory Processes Mediating between Career Calling and Perceived Employability and Life Satisfaction in Emerging Adults
}

Anna Praskova, Peter Creed, and Michelle Hood School of Applied Psychology and Menzies Health Institute Queensland

Contact: Prof Peter Creed p.creed@griffith.edu.au

\section{PAPER CAN BE CITED AS:}

Praskova, A., Creed, P. A., \& Hood, M. (2015). Self-regulatory processes mediating between career calling and perceived employability and life satisfaction in emerging adults. Journal of Career Development, 42, 86-101. doi:10.1177/0894845314541517 


\begin{abstract}
We tested a mediation model of career calling, in which career calling was associated positively with life satisfaction and perceptions of future employability, and these relationships were explained by the self-regulatory mechanisms of work effort, career strategies, and emotional regulation. Using a sample of 664 emerging adults ( $74.8 \%$ female, mean age $=20.2$ years), we found that higher career calling was associated with better life satisfaction and more positive perceived employability, that higher career calling was associated with more work effort, more use of career strategies, and better emotional regulation, and that the self-regulatory strategies mediated between career calling and life satisfaction (work effort and emotional regulation) and between career calling and perceived employability (work effort, emotional regulation, and career strategies). We interpreted the results from a developmental and goal-setting perspective, and made recommendations for practice.
\end{abstract}

Keywords: career calling; self-regulation; life satisfaction; perceived employability; emerging adults 


\section{Self-Regulatory Processes Mediating between Career Calling and Perceived Employability and Life Satisfaction in Emerging Adults}

“What is my purpose in life?” “Is my chosen career going to be meaningful?” Questions like these surface when young people are deciding on their career, commencing tertiary studies, or contemplating entry to the labour market (Weiss, Skelley, Haughey, \& Hall, 2004). Ideally, young people settle on a career that is meaningful to them and involves activities that are personally significant. When they do this, they can be said to have developed a career calling (Bellah, Madsen, Sullivan, Swidler, \& Tipton, 1985; Colozzi \& Colozzi, 2000). A career calling, or dominant career-related goal, stimulates purposeful, goaldirected actions that facilitate them moving closer to their desired occupational future (Damon, Menon, \& Cotton Bronk, 2003; Rosso, Dekas, \& Wrzesniewski, 2010). Past research suggests that about $40 \%$ of emerging adults experience a strong career calling (Duffy \& Sedlacek, 2010), with those who do benefiting from better well-being, more satisfactory career development, and better occupational adjustment (Duffy, Allan, \& Dik, 2011; Duffy, Manuel, Borges, \& Bott, 2011; Steger, Pickering, Shin, \& Dik, 2010). Unfortunately, many young people are still unclear about their career direction when they enter the full-time labour market and remain dissatisfied later on in their working life (Colozzi \& Colozzi, 2000; Dik, Eldridge, Steger, \& Duffy 2012).

Thus, it is important to gain a greater understanding of the career calling concept and its correlates in order to assist young people to formulate clear, meaningful, and purposeful career goals from which they can benefit. While there is a renewed interest in the effects of career calling and how it is associated with work meaning (Weiss et al., 2004), career satisfaction, personal well-being, and growth (Elangovan, Pinder, \& McLean, 2010; Hall \& Chandler, 2005; Weiss et al., 2004), research with young people that investigates more complex relationships surrounding career calling is limited (e.g., Duffy, Allan, \& Bott, 2012; 
Hirschi \& Hermann, 2013; Steger et al., 2010). This study aimed to add to this growing literature by testing whether self-regulatory processes mediate the relationships between career calling and well-being and occupational attitudes (see Figure 1). We tested our hypotheses using a sample of emerging adults, as settling on a career pathway is critical for this age group (Shulman \& Nurmi, 2010), and took a goal-setting perspective (Locke \& Latham, 1990), as career calling reflects goal setting in the career domain. Goal setting theory proposes that people consciously and unconsciously set goals, or have them set by others, and choose and apply actions and self-regulatory processes to help them reach these future goals.

\section{Career Calling}

Career calling is core to the holistic understanding of work and life (Dik \& Duffy, 2009). To date, there is no agreement over the definition of career calling (Elangovan et al., 2010; Hall \& Chandler, 2005), although there is consensus that people with a calling consider their work to be deeply meaningful, and approach it with a strong sense of purpose and desire to contribute to others in the community (Dik \& Duffy, 2009; Elangovan et al., 2010; Hall \& Chandler, 2005; Steger et al., 2010). Variously, career calling has been defined as any work oriented towards deriving a strong sense of purpose and meaning from fulfilling otheroriented values and goals (Dik \& Duffy, 2009), a place in the labour market that one feels destined to fill by virtue of one's own talents and life opportunities (Bunderson \& Thompson, 2009), orientation towards work that is inseparable from one’s life (Bellah et al., 1985), work that is perceived as one’s purpose in life (Hall \& Chandler, 2005), a consuming, meaningful passion towards a specific domain (Dobrow \& Tosti-Kharas, 2011), or a course of action in pursuit of pro-social intentions (Elangovan et al., 2010).

Career calling has strong religious and humanitarian connotations, as for many centuries, calling referred to religious work (Dik \& Duffy, 2009; Weiss et al., 2004). Contemporary writings do refer to God's mission to serve others, but also indicate that a calling can 
originate from other external sources, such as acting on social needs, family legacy, or some unknown drive (Bunderson \& Thompson, 2009; Dik \& Duffy, 2009). Additionally, with the emphasis on continuous learning and adaptability in changing work environments, and the push for personal and professional development (Hall \& Chandler, 2005; Weiss et al., 2004), new conceptualisations now highlight that a career calling predominantly originates within the individual, and is central to one's identity. These secular perspectives recognise personal effort in finding and adapting a calling that generates a strong sense of personal and selfrelevant meaning and purpose in life, derives enjoyment and self-fulfilment, and stimulates inner direction and action-orientation in pursuit of that calling (Dobrow \& Tosti-Kharas, 2011; Elangovan et al., 2010; Hall \& Chandler, 2005). Consistent with these views, career calling is increasingly regarded as a developmental and dynamic construct (Elangovan et al., 2010; Weiss et al., 2004), which might begin before one is work-ready, and which can be adapted in changing circumstances and shaped by other external factors, such as by observing parents’ attitudes towards their work (Rosso et al., 2010; Wrzesniewski, 2012).

\section{Career Calling, Goal Setting, and Emerging Adults}

The developmental stage of “emerging adulthood” is the period between adolescence and adulthood, and traditionally encompasses the transition from high school to work or further education and training (i.e., approximately 18 to 25 years; Arnett, 2000). During this period, emerging adults relinquish earlier goals, establish new ones, make decisions about their future career and life, and plan and initiate actions to achieve them (Havighurst, 1953/1961; Shulman \& Nurmi, 2010). Career calling becomes important for emerging adults as they develop career goals and engage in career actions relevant to creating a meaningful occupational future (Berg, Grant, \& Johnson, 2010). This view is consistent with the goalsetting theory of motivation (Locke \& Latham, 1990), which proposes that individuals set goals or have goals set for them, and that these goals help them organise their behaviours, 
motivate and energise them, and guide their actions. Motivation and actions, which are reflected in self-regulatory and goal adjustment strategies, are stimulated by perceived discrepancies between future goals and current behaviours or situations (i.e., stimulated by goal-behaviour discrepancies; Bandura, 1991; Locke \& Latham, 2006). Goal-setting theory is consistent with other goal-setting, evaluating, and regulating models, such as Bandura's social cognitive theory (1991), social cognitive career theory (Lent, Brown, \& Hackett, 1994), and control theory (Carver \& Scheier, 1998), and is well placed to explain the development and management of career goals and career goal-pursuit behaviours.

Based on developmental and goal-setting perspectives, career calling in emerging adults is manifested differently to that of adults in work, who are, for example, already living a calling (Duffy et al., 2012). Career calling is consistent with identifying strong personal goals, and is manifested in future-oriented actions, cognitions, and emotions relevant to the management and pursuit of the goals. From this perspective, career calling in emerging adulthood can be represented as a "mostly self-set, salient, career goal that is meaningful and purposeful, and has the potential to grow or be adjusted by engaging in goal-directed, careerpreparatory actions and adaptive processes aimed at meeting this goal” (Praskova, Creed, \& Hood, in press).

\section{Career Calling and Self-Regulation}

Goals, which refer to future valued outcomes, trigger motivational and behavioural selfregulatory processes, which, in turn, assist with goal attainment as they enable the individual to guide and sustain goal-directed activities and commitment over time and across changing circumstances (Kanfer, Ackerman, \& Heggestad, 1996; Karoly, 1993; Locke \& Latham, 1990). Specifically, individuals with high, specific goals increase their work effort (motivational mechanisms) by focussing their attention on pursuing the goal, intensifying their work, and persisting on their goal-directed activities (De Cooman, De Gieter, 
Pepermans, Jegers, \& van Acker, 2009). Individuals also use task-related knowledge and selfregulatory strategies in goal pursuit (behavioural mechanisms; Latham, Borgogni, \& Petita, 2008; Locke \& Latham, 1990). In emerging adults, these might include developing knowledge in the area of their chosen career, networking, seeking information from experts, problem solving, and planning, all of which help them manage obstacles and guide their career goal-directed actions (Savickas, 1999). Finally, emotional control is considered an important regulatory mechanism, which facilitates learning, problem solving, and task persistence, helps to manage off-task concerns and emotions that divert attention away from goal pursuit, and contributes to well-being (Kanfer et al., 1996; Kuhl, 1985). Control over one's emotional reactions is especially important at the start of a learning process (Kanfer et al., 1996), and thus is relevant for emerging adults as they set career goals, enrol in careerrelevant training, and face daunting periods of learning cycles, successes, and failures.

There is a consensus that individuals with a career calling also engage in various behavioural and psychological processes that direct their attention towards meaningful career-related activities (Elangovan et al., 2010; Grant, 2007) and increase their vocational effort and focus (Hall \& Chandler, 2005). From the limited research on self-regulation in emerging adults, greater career calling is associated with engaging in more career activities, having more educational information and career insight, and showing more career planning (Dobrow \& Tosti-Kharas, 2011; Duffy \& Sedlacek, 2007; Hirschi \& Hermann, 2013).

Qualitative research has found links between having a career calling and increased effort and dedication (Hunter, Dik, \& Banning, 2010). From this, we expected that career calling would be associated positively with career self-regulatory behaviours.

\section{Career Calling and Well-Being}

Well-being, which can be conceptualised as an overall cognitive judgement of one's life (Diener, Emmons, Larsen, \& Griffin, 1985), plays a central role in positive youth 
development, and is related to young people realising their abilities, coping with the stresses of life, and working productively towards their goals (Park, 2004). Individuals who are motivated to reach a "stable and far-reaching goal", one that is meaningful to the self and carries consequences to the world beyond the self, benefit from more positive outcomes (e.g., having higher self-esteem and more developed identity; Damon et al., 2003, p.121), and are protected against negative emotions and poor well-being, such as depression and anxiety (Dik \& Duffy, 2009). Thus, emerging adults with higher career calling should benefit from better well-being compared to those with lower levels. In support of this, career calling in emerging adults is associated with more positive outcomes in various forms of well-being, such as life satisfaction (Duffy et al., 2012), academic satisfaction (Duffy, Allan, et al., 2011), positive affect (Vallerand et al., 2003), work enjoyment, and passion (Dobrow \& Tosti-Kharas, 2011).

\section{Career Calling and Perceived Employability}

The construct of employability has become increasingly relevant as world economic markets and conditions become more turbulent (Rothwell, Herbert, \& Rothwell, 2008). In the $21^{\text {st }}$ Century, individuals need to be more active and adaptable in order to realise their career opportunities (Fugate, Kinicki, \& Ashfort, 2004) and cope effectively with career transitions (Wittekind, Raeder, \& Grote, 2010). As many emerging adults invest in costly, long-term educational programs, but still face job insecurity after this, it is important to develop employability skills and perceptions early on, as these will help them gain employment and cope with labour downturns in the future. Perceived employability in emerging adults mirrors their “self-perceived ability to attain sustainable employment appropriate to one’s qualification level” (Rothwell et al., 2008, p. 2). It reflects internal factors, such as relatively high confidence in, and valuation of, one's career-related skills and abilities, and external factors, such as positive perceptions about the labour market.

In the context of goal-setting theory, perceived employability reflects a belief about future 
goal attainment (Wittekind et al., 2010). Emerging adults with a stronger career calling should display stronger beliefs about their future employability as they are more self-defined (i.e., have a stronger career identity), more motivated (Fugate et al., 2004), and have established higher goals, which are related to greater self-confidence and expectations about their performance (Seijts, Latham, Tasa, \& Brandon, 2004). Consistent with this, career calling is associated positively with career self-efficacy and outcome expectations (Dik, Sargent, \& Steger, 2008; Hirschi, 2011), and perceiving work as important for life is associated with greater certainty about achieving one’s future occupation (Tryon \& Radzin, 1972) and being more employable (De Vos, De Stobbeleir, \& Meganck, 2009).

\section{Self-Regulation, Well-Being, and Perceived Employability}

Self-regulation, or the adaptive tendency used in goal pursuit, fosters well-being (Kuhl, Kazen, \& Koole, 2006) and is important for emerging adults in the context of their development of employability (van der Heijden, 2002). Individuals with more effective selfregulation strategies are more motivated, better able to control negative anxiety-related events, cope with career changes, and manage their own career in the desired direction (De Vos et al., 2009; Fugate et al., 2004; Hall \& Chandler, 2005; Rapee, Craske, Brown, \& Barlow, 1996; Savickas, 1999). Research supports this. For example, increased career commitment predicted job satisfaction in an adult sample (Duffy, Dik, \& Steger, 2011), greater career adaptability was associated with fewer career concerns among emerging adults (Creed, Fallon, \& Hood, 2009), and the use of career self-management strategies (e.g., networking, self-control, and career knowledge), were associated with perceived employability among university students (De Vos et al., 2009; van der Heijden, 2002).

\section{Self-Regulation as a Mediator}

Motivational, behavioural, and emotional self-regulatory processes act as driving forces in the goal-outcome relationship (Kanfer \& Heggestad, 1997; Locke \& Latham, 1990). 
Consistent with this, Fugate et al. (2004) argued that individuals with a strong sense of career identity (i.e., who have already established a salient career goal) were motivated to actively create, adapt, and engage in activities that matched their career aspirations, and these led to perceptions of greater employability. In the calling literature, Hall and Chandler (2005) proposed a model consistent with goal-setting perspectives, and argued that the sense of purpose in a calling would lead to increased goal effort, which, in turn, would lead to greater psychological and objective career success. This means that having a stronger career calling in emerging adulthood should trigger various self-regulatory mechanisms used to assist with reaching desired goals, which, in turn, should lead to positive outcomes. From the handful of career calling studies on self-regulatory mediators, work hope (considered motivational) fully mediated the relationship between career calling and academic satisfaction in emerging adults (Duffy et al., 2012), and career commitment fully mediated the relationship between career calling and job satisfaction in adults (Duffy, Dik, et al., 2011).

\section{Present Study}

There is limited understanding of the various processes that individuals utilise when they pursue their calling and how these processes influence their meaning of work (Rosso et al., 2010). To date, no research on career calling has assessed a comprehensive range of selfregulatory processes identified as crucial mechanisms in goal progress (Kanfer et al., 1996; Grant, 2007; Latham et al., 2008). We aimed to address this deficit. We tested a crosssectional, goal-setting model, where career calling was the salient, meaningful, career goal, well-being and perceived employability were important individual outcomes, and selfregulatory strategies acted as mediators between career calling and well-being and employment attitudes (see Figure 1). Specifically, we hypothesised that higher levels of career calling in emerging adults would be associated with greater motivation (operationalized as work effort), greater use of behavioural strategies (operationalized as 
career self-management strategies), and greater emotional self-regulation (operationalized as emotional control). These self-regulatory processes would, in turn, be related to higher wellbeing (operationalized as life satisfaction) and greater self-perceived employability. Additionally, we expected that, after controlling for the effects of the self-regulatory mechanisms, the direct relationships between career calling and well-being, and career calling and perceived employability, would be reduced significantly (i.e., that the selfregulatory strategies would act as mediators).

\section{Method}

\section{Participants}

Our sample consisted of 664 emerging adults (74.8\% female), with a mean age of 20.23 years $(S D=2.56$, range 17 to 25$)$. The mean achievement level at high school was $1.97(S D=$ 0.70; “What grade did you typically receive in your final year at high school?”), on a 5-point Likert-type scale ( 1 = very high achievement, 5 = very limited achievement). The majority were university (89\%) or vocational training college students (7\%) enrolled across a diverse range of degree programs (e.g., health, arts, education, law, business, and science), vocational certificates, diplomas, and apprenticeships (e.g., hospitality, electrician, event management, youth work, and retail). The remainder were either employed (2\%) or unemployed (1\%). Nine participants (1\%) did not answer this question.

\section{Measures}

Unless otherwise stated, all scales used a 6-point Likert-like format (1 = strongly disagree to 6 = strongly agree), with higher scores reflecting higher levels of the respective constructs.

Career Calling. A 15-item scale developed for use with emerging adults was used to assess cognitive, behavioural, and affective aspects of career calling across three domains of personal meaning (e.g., "Preparing for my career is contributing to my personal growth”), other-oriented meaning (e.g., "It is my calling to benefit others in my future chosen career”), 
and purposeful directedness (e.g., "Everything I do to prepare for my career is enjoyable and draws me towards it”; Praskova et al., in press). Internal reliability for the full scale and subscales were $>.80$, and confirmatory factor analysis supported the factor structure. The measure was distinguished from search for calling, and showed correlations in the predicted direction with measures of career indecision, presence of calling, and life satisfaction. Alphas in the current study were .89 (full scale), .81 (personal meaning), .85 (other-oriented meaning), and .82 (purposeful directedness).

Self-Regulation. Three scales were used to measure self-regulatory strategies.

Motivational self-regulation. The 10-item Work Effort Scale (De Cooman et al., 2009) taps three domains of work effort: direction, intensity, and persistence. Several items were modified to suit our sample of emerging adults (e.g., the item, "I really do my best in my job”, was amended to, "I really do my best in everything I have to do"). De Cooman et al. (2009) reported an internal reliability coefficient of .90 and a 3-week test-retest correlation of .72 in their sample of adult employees, and in support of validity, the scale demonstrated correlations in the predicted direction with self-reported performance and job satisfaction. The internal reliability coefficient for our sample was .94.

Behavioural self-regulation. The 26-item Career Strategies Inventory (Gould \& Penley, 1984) taps a range of career enhancing strategies, including creating career opportunities, self-presentation, work involvement, and seeking career guidance. The items were amended to reflect the first person, and several items were modified to suit emerging adults who were contemplating their future career. In response to this stem, "In respect to my career future, I am...”, participants responded to questions such as, “...dressing like influential people”. Perkins (2012) used this amended scale with emerging adults and found a single factor, internal reliability coefficient of .91 , and expected associations with other career variables. Internal reliability for our sample was .92. 
Emotional self-regulation. The 9-item Emotion Reduction Subscale from the Emotion Amplification and Reduction Scales (Hamilton et al., 2009) assessed the extent to which participants exhibited control over their concerns by reducing, shortening, or stopping emotional responses. Participants responded to items such as, "I can stop an emotion before it overwhelms me”, on a 6-point Likert-like scale with endpoints of $1=$ not at all true for me and 6 = very true for me. Hamilton et al. (2009) reported an internal reliability of .89 for the subscale with undergraduate students and found expected associations with negative affect, depressive symptoms, and fatigue. Alpha in our sample was .93.

Well-Being. The 5-item Satisfaction with Life Scale (Diener et al., 1985) was used to assess general satisfaction with life. A sample item is, "I'm satisfied with my life”. The scale has demonstrated good psychometric properties with undergraduate students, including an internal reliability coefficient of .87, a 2-month test-retest reliability of .82, and correlations with other scales in the expected direction (Diener et al., 1985). The internal reliability coefficient for our sample was .89.

Perceived Employability. The 16-item Self-Perceived Employability Scale (Rothwell \& Arnold, 2007) assesses individuals' perceptions of their attractiveness and worth in the labour market. Items were modified to suit emerging adults who were anticipating entry to full-time employment. For example, the item, "People who do the same job as me are valued highly", was amended to, "People with the same career choice as me are highly valued”. Rothwell and Arnold (2007) reported an internal consistency of .83 with employed adults and expected correlations with career success and professional commitment. Alpha for our sample was .91.

\section{Procedure}

This study is part of a larger project, examining career development in emerging adults (Praskova et al., in press). Approval was granted by the authors' university ethics committee, and the survey was distributed both online and in paper-and-pencil format. As an incentive, 
participants were able to enter a prize draw for a $\$ 50$ shopping voucher.

\section{Results}

Data screening revealed a small portion of missing values (0.4\%; 195 values). Little’s omnibus MCAR test indicated these were missing completely at random, $\chi^{2}(1115, N=664)=$ 1149.38, $p=.23$, which allowed for data replacement using imputation methods available in SPSS. Parcelling was employed to form observed variables to represent the latent variables for the longer scales of work effort, emotional regulation, career strategies, and employability (Landis, Beal, \& Tesluck, 2000). Parcels were formed by conducting separate exploratory factor analyses for each scale, rank ordering the factor loadings within each scale, and then allocating the individual items to one of three parcels using an item-to-construct balance approach (Hau \& Marsh, 2004). The three parcels for career calling were represented by the three subscales of the scale. Life satisfaction was represented by the five individual items.

Using structural equation modelling (i.e., maximum likelihood estimation in AMOS 21), we assessed a measurement model to confirm that the latent variables were represented by their parcels or observed variables, and then assessed the hypothesized structural model in Figure 1. We followed Hair, Black, Babin, and Anderson’s (2010) recommendations for a sample $\geq 250$ participants with $>12$ observed variables, and assessed model fit using Chisquare $\left(\chi^{2}\right.$; significant $p$ value expected $)$, the Normed Chi-square $\left(\chi^{2} / d f<3.0\right.$ suggests a good fit), the Comparative Fit Index (CFI > .92 expected), the Tucker-Lewis Index (TLI > .92), the Goodness of Fit Index (GFI > .90), the Root Mean-Square Error of Approximation (RMSEA $<.07)$, and the Standardised Root Mean-Square Residual (SRMR $\leq .08)$.

\section{Testing the Measurement Model}

The measurement model showed good fit statistics for the six latent variables: $\chi^{2}(152)=$ $393.15, p=.005, \chi^{2} / d f=2.59, \mathrm{GFI}=.95, \mathrm{SRMR}=.04, \mathrm{CFI}=.98, \mathrm{TLI}=.97$, and RMSEA $=$ .05, and contained no problematic cross-loadings. Standardised loadings on the latent variable 
were all significant ( $p<.001$; range .53 to .96), supporting construct validity of the scales. The correlations among the latent variables were all significant $(p<.001)$, ranging from .25 to .68 (see Table 1 for summary data).

\section{Testing the Structural Model}

Age and gender were not associated with either of the outcome variables (see Table 1), and thus were not included in the model as covariates. The hypothesised model showed a good fit: $\chi^{2}(158)=461.86, p=.001, \chi^{2} / d f=2.92, \mathrm{GFI}=.94, \mathrm{SRMR}=.06, \mathrm{CFI}=.97, \mathrm{TLI}=$ .97 , and RMSEA $=.05$. As seen in Figure 2 , significant positive paths $(p<.001)$ were found from career calling to work effort, emotional regulation, and career strategies, indicating that, as expected, higher levels of career calling were associated with more work effort, emotional regulation, and use of career strategies. Also, there were significant positive paths $(p<.001)$ from work effort and emotional regulation to perceived employability and life satisfaction, and a significant positive path from career strategies to perceived employability $(p<.001)$. These anticipated results indicate that higher levels of work effort, emotional regulation, and career strategies were associated with greater perceived employability, and that higher levels of work effort and emotional regulation were associated with more life satisfaction. The path from career strategies to life satisfaction was not significant $(\beta=.04, p=.41)$, indicating no support for the hypothesis that career strategies was associated with life satisfaction. Figure 2 depicts the final model with the non-significant path removed for clarity.

\section{Testing for Mediation}

From the above analyses, work effort, emotional regulation, and career strategies potentially mediated the relationships between career calling and perceived employability and life satisfaction. Four criteria must be met for mediation: the predictor must be associated with both the mediator and the outcome variable, the mediator must be associated with the outcome variable, and the strength of the relationship between the predictor and the outcome 
variable must be reduced significantly (partial mediation) or reduced to zero (full mediation) in the presence of the mediator (Baron \& Kenny, 1986). The previous analyses demonstrated that career calling was associated with all three mediators, that the three mediators were associated with perceived employability, and that two mediators (work effort and emotional regulation) were associated with life satisfaction. When we assessed the direct effects of career calling on the outcome variables (perceived employability and life satisfaction), both estimates were significant, with standardised coefficients of .74 and .42 $(p<.001)$, respectively. Finally, we used bootstrapping (1000 bootstrapped samples; Preacher \& Hayes, 2008) to assess the indirect effects between career calling and perceived employability and life satisfaction via the mediators. Bootstrapping generates standard errors and 95\% biascorrected confidence intervals. Mediation is indicated when the $95 \%$ confidence interval of the indirect effect does not include zero. For both career calling on perceived employability $\left(\mathrm{CI}_{95}=.25\right.$ to .51$)$ and career calling on life satisfaction $\left(\mathrm{CI}_{95}=.20\right.$ to .35$)$, the confidence intervals did not contain zero, indicating that the career calling-outcome relationships were mediated by the self-regulatory variables. As the direct path from career calling to perceived employability remained significant in the presence of the mediators $(\beta=.22, p=.002)$, the mediation between these two variables was partial. The total effect of career calling on perceived employability explained $37.33 \%$ of the variance, with $15.05 \%$ of the variance being explained by the indirect effect through the mediators. In terms of life satisfaction, the direct path between career calling and life satisfaction was non-significant in the presence of the mediators ( $\beta=.04, p=.44)$, indicating full mediation. Consistent with this, the total effect of career calling on life satisfaction explained $9.92 \%$ of the variance, with $7.45 \%$ of the variance being due to the indirect effect through the mediators.

We probed the specific indirect effects using RMediation, which computes confidence intervals for the indirect effects on the basis of the distribution of the product of regression 
coefficients (Tofighi \& MacKinnon, 2011). This method is useful in multiple mediator models for testing specific mediated effects (Fritz \& MacKinnon, 2012). The results here indicated that all five possible mediating paths were significant (i.e., the $95 \%$ confidence intervals did not include zero). The effect of career calling on perceived employability was mediated by work effort $\left(\mathrm{CI}_{95}=.01\right.$ to .09$)$, emotional regulation $\left(\mathrm{CI}_{95}=.03\right.$ to .08$)$, and career strategies $\left(\mathrm{CI}_{95}=.16\right.$ to .32), while the effect of career calling on life satisfaction was mediated by work effort $\left(\mathrm{CI}_{95}=.03\right.$ to .06$)$ and emotional regulation $\left(\mathrm{CI}_{95}=.02\right.$ to .04$)$.

\section{Discussion}

This study tested a mediation model of goal setting, in which career calling was associated with better life satisfaction and a better perception of future employability, and these relationships were explained by use of self-regulatory mechanisms (i.e., increased work effort, career strategies, and emotional regulation). Consistent with previous research assessing the relationships between career calling and well-being (Duffy et al., 2012) and between work importance and perceptions of employability (De Vos et al., 2009), our study showed that higher career calling was associated with both higher life satisfaction and more positive perceived employability. Also, consistent with propositions that individuals with a higher career calling engage in more self-regulatory processes to guide their attention and goal progress (Elangovan et al., 2010; Hall \& Chandler, 2005), our study showed that emerging adults higher on career calling reported more work effort, had better control of their emotions, and used more career developmental strategies.

While the positive relationship between career calling and well-being has been found in the career calling research area, we add to this literature by using an age-appropriate measure of calling to test the relationship with emerging adults, who are initiating career actions in preparation for achieving meaningful work as adults. We also contribute to the literature by taking a theoretical approach in identifying new correlates of career calling. Self-regulatory 
processes are recognised as important constructs in goal setting (Locke \& Latham, 1990; Kanfer \& Heggestad, 1997), and consistent with developmental approaches (Havighurst, 1953/1961; Shulman \& Nurmi, 2010), we selected variables that are salient for the career development and adaptability of emerging adults, which needs to be future-oriented, learning and action focused, and responsive to today's labour market demands (Rothwell et al., 2008).

Most importantly, we responded to calls to investigate potential mediators between career calling, vocational development, and well-being (Duffy, Manuel, et al., 2011), and assessed the effects of self-regulation on perceived employability (Wittekind et al., 2010). Our study showed that a higher career calling was associated with more work effort, emotional regulation, and career strategies, which, in turn, were associated with more life satisfaction (work effort and emotional regulation) and more positive perceptions of employability (work effort, emotional regulation, and career strategies). The combined mediation effects were of moderate strength, indicating that the self-regulatory effects were meaningful, and when probed, it was shown that all self-regulation variables made a contribution. Our findings are consistent with related mediation research on the career calling/well-being relationship (Duffy et al., 2012; Duffy, Dik, et al., 2011), and consistent with Hall and Chandler’s (2005) approach to career success and goal setting perspectives (Kanfer \& Heggestad, 1997; Locke \& Latham, 1990), which propose that higher goals (i.e., career calling) stimulate motivational (i.e., work effort), behavioural (i.e., strategies), and emotional (i.e., ability to control emotions) regulatory processes that act as driving forces for goal accomplishment and better well-being. As all self-regulatory mechanisms are considered to work in concert during goal progress (Locke \& Latham, 1990), which helps explain the weaker effects found for the individual pathways, future research might test models that include moderated-mediation pathways to assess these combined effects.

Of all the predictors, career strategies had the strongest relationship with employability; 
but, contrary to our expectations, this variable was not associated with life satisfaction, and did not mediate the path between career calling and life satisfaction, after controlling for the other variables in the model. There are several potential explanations for this. First, our measure of well-being was general, rather than context-specific (e.g., career satisfaction), which might explain this result. Second, career calling, which is associated with life meaning (Duffy \& Sedlacek, 2010), might stimulate more general motivational and emotional selfregulatory processes, and be less connected to specific, career-related strategies. Third, goalsetting theory (Locke \& Latham, 1990) posits that setting a high goal is more motivating for individuals because it requires them to achieve more in order to be satisfied. Based on this, satisfaction derives from individuals’ perception that they are growing professionally and have perceptions of successful goal attainment. Future studies could assess this in a longitudinal study that places life satisfaction as a consequence of perceived employability.

Regarding practical applications, individuals who lack a meaning and purpose in life are thought to be frustrated with their existence (Frankl, 1984) and to be prone to negative outcomes, such as negative emotions, depression, and anxiety (Dik \& Duffy, 2009). The participants in our study who had lower career calling reported less use of self-regulatory strategies, and reported poorer well-being and less positive views of their future. There are implications here for educational and counselling programs that are aimed at fostering a sense of purpose and meaning, both occupationally and in life in general. Such programs could promote development of a healthy, adaptive, and active career calling long before young people are in the transition-to-work phase, and before they are work-ready. Such programs could commence by identifying important and purposeful goals, values, and interests in the person's life that might develop into significant work and life aspirations. They also could focus on educating young people about the positive effects that having a meaningful and purposeful career goal has on self-confidence, well-being, and professional behaviours (e.g., 
consulting experts, exploring career choice, networking), their learning, career pursuit focus and persistence (i.e., maintaining direction, intensity, and persistence), and their ability to overcome negative emotions related to potential concerns.

Although our study yielded promising results regarding the career development and career goal pursuit of emerging adults, we have not established generalizability. Gender and educational attainment were not associated with the outcome variables, but we had disproportionally more young women than men, and more students than non-students, in our sample. Future studies need to test the relationships on more diverse samples. Second, although we used sophisticated statistical methods to test plausible causal relationships, our research was cross-sectional. Employing a longitudinal design would allow for tracking individual trajectories over time, and permit stronger causal interpretations. Finally, our mediator variables were largely internal self-regulatory strategies, and did not reflect the individual's capacity to marshal support and resources from others (Shulman, Feldman, Blatt, \& Coen, 2005). For example, social support has been shown to be related to both employability and well-being (see Rothwell et al., 2008). Thus, while we tested crucial selfregulatory processes involved in the pursuit of a career calling in emerging adulthood, our selection was not exhaustive. Future research might include strategies both internal and external to the person to assess the relative strength of each of these relationships, and to account for more variance in the outcome variables. By furthering our understanding of the driving forces behind goal pursuit, we can help young people to realise their career dreams, continue to grow, and achieve the lives they desire.

\section{References}

Arnett, J. J. (2000). Emerging adulthood: A theory of development from the late teens through the twenties. American Psychologist, 55, 469-480. doi:10.1037/0003066X.55.5.469 
Bandura, A. (1991). Social cognitive theory of self-regulation. Organizational Behavior and Human Decision Processes, 50, 248-287. doi:10.1016/0749-5978(91)90022-L

Bellah, R. N., Madsen, R., Sullivan, W. M., Swidler, A., \& Tipton, S. M. (1985). Habits of the heart. New York, NY: Harper \& Row.

Berg, J. M., Grant, A. M., \& Johnson, V. (2010). When callings are calling: Crafting work and leisure in pursuit of unanswered occupational callings. Organization Science, 21, 973-994. doi:10.1287/orsc.1090.0497

Baron, R., \& Kenny, D. (1986). The moderator-mediator variable distinction in social psychological research: Conceptual, strategic, and statistical considerations. Journal of Personality and Social Psychology, 5, 1173-1182. doi:10.1037/0022-3514.51.6.1173

Bunderson, J. S., \& Thompson, J. A. (2009). The call of the wild: Zookeepers, callings, and the double-edged sword of deeply meaningful work. Administrative Science Quarterly, 54, 32-57. doi:10.2189/asqu.2009.54.1.32

Carver, C. S., \& Scheier, M. F. (1998). On the self-regulation of behavior. Cambridge, UK: Cambridge University Press.

Colozzi, E. A., \& Colozzi, L. C. (2000). College students' callings and careers: An integrated values-oriented perspective. In D. A. Luzzo (Ed.), Career counselling of college students (pp. 63-91). Washington, DC: American Psychological Association.

Creed, P. A., Fallon, T., \& Hood, M. (2009). The relationship between career adaptability, person and situation variables, and concerns in young adults. Journal of Vocational Behavior, 74, 219-229. doi:10.1016/j.jvb.2008.12.004

Damon, W., Menon, J., \& Cotton Bronk, K. (2003). The development of purpose during adolescence. Applied Developmental Science, 7, 119-128. doi:10.1207/s1532480xads0703_2

De Cooman, R., De Gieter, S., Pepermans, R., Jegers, M., \& van Acker, F. (2009). 
Development and validation of the Work Effort Scale. European Journal of Psychological Assessment, 25, 266-273. doi:10.1027/1015-5759.25.4.266

De Vos, A., De Stobbeleir, K., \& Meganck, A. (2009). The relationship between careerrelated antecedents and graduates’ anticipatory psychological contracts. Journal of Business \& Psychology, 24, 289-298. doi:10.1007/s10869-009-9107-3

Diener, E., Emmons, R. A., Larsen, R. J., \& Griffin, S. (1985). The Satisfaction with Life Scale. Journal of Personality Assessment, 49, 71-75. doi:10.1207/s15327752jpa4901_13

Dik, B. J., \& Duffy, R. D. (2009). Calling and vocation at work. The Counseling Psychologist, 37, 424-450. doi:10.1177/0011000008316430

Dik, B. J., Eldridge, B. M., Steger, M. F., \& Duffy, R. D. (2012). Development and validation of the Calling and Vocation Questionnaire (CVQ) and Brief Calling Scale (BCS). Journal of Career Assessment, 20, 242-263. doi:10.1177/1069072711434410

Dik, B. J., Sargent, A. M., \& Steger, M. F. (2008). Career development strivings: Assessing goals and motivation in career decision-making and planning. Journal of Career Development, 35, 23-41. doi:10.1177/0894845308317934

Dobrow, S. R., \& Tosti-Kharas, J. (2011). Calling: The development of a scale measure. Personnel Psychology, 64, 1001-1049. doi:10.1111/j.1744-6570.2011.01234.x

Duffy, R. D., Allan, B. A., \& Bott, E. M. (2012). Calling and life satisfaction among undergraduate students: Investigating mediators and moderators. Journal of Happiness Studies, 13, 469-479. doi:10.1007/s10902-011-9274-6

Duffy, R. D., Allan, B. A., \& Dik, B. J. (2011). The presence of a calling and academic satisfaction: Examining potential mediators. Journal of Vocational Behavior, 79, 74-80. doi:10.1016/j.jvb.2010.11.001

Duffy, R. D., Dik, B. J., \& Steger, M. F. (2011). Calling and work-related outcomes: Career commitment as a mediator. Journal of Vocational Behavior, 78, 210-218. 
doi:10.1016/j.jvb.2010.09.013

Duffy, R. D., Manuel, R. S., Borges, N. J., \& Bott, E. M. (2011). Calling, vocational development, and well being: A longitudinal study of medical students. Journal of Vocational Behavior, 79, 361-366. doi:10.1016/j.jvb.2011.03.023

Duffy, R. D., \& Sedlacek, W. E. (2007). The presence of and search for a calling: Connections to career development. Journal of Vocational Behavior, 70, 590-601. doi:10.1016/j.jvb.2007.03.007

Duffy, R. D., \& Sedlacek, W. E. (2010). The salience of a career calling among college students: Exploring group differences and links to religiousness, life meaning, and life satisfaction. The Career Development Quarterly, 59, 27-41. Retrieved from http://search.proquest.com

Elangovan, A. R., Pinder, C. C., \& McLean, M. (2010). Callings and organizational behavior. Journal of Vocational Behavior, 76, 428-440. doi:10.1016/j.jvb.2009.10.009

Frankl, V. (1984). Man’s search for meaning. New York, NY: Pocket Books.

Fritz, M., S., \& MacKinnon, D. P. (2012). Mediation models for developmental data. In B. Laursen, T. D. Little, \& N. A. Card (Eds.) Handbook of developmental research methods (pp. 291-310). New York, NY: The Guilford Press.

Fugate, M., Kinicki, A., J., \& Ashforth, B. E. (2004). Employability: A psycho-social construct, its dimensions, and applications. Journal of Vocational Behavior, 65, 14-38. doi:10.1016/j.jvb.2003.10.005

Gould, S., \& Penley, L. E. (1984). Career strategies and salary progression. Organizational Behavior and Human Performance, 34, 244-265. doi:10.1016/0030-5073(84)90006-0

Grant, A. M. (2007). Relational job design and the motivation to make a prosocial difference. Academy of Management Review, 32, 393-417. doi:10.5465/AMR.2007.24351328

Hair, J. F., Black, W. C., Babin, B. J., Anderson, R. E. (2010). Multivariate data analysis. A 
global perspective. ( $7^{\text {th }}$ ed.). New Jersey, NJ: Prentice Hall.

Hall, D. T., \& Chandler, D. E. (2005). Psychological success: When the career is a calling. Journal of Organizational Behavior, 26, 155-176. doi:10.1002/job.301

Hamilton, N. A., Karoly, P, Gallagher, M., Stevens, N., Karlson, C., \& McCurdy, D. (2009). The assessment of emotion regulation in cognitive context. Cognitive Therapies Research, 33, 255-263. doi:10.1007/s10608-007-9163-9

Hau, K., \& Marsh, H. W. (2004). The use of item parcels in structural equation modelling: Non-normal data and small sample sizes. British Journal of Mathematical and Statistical Psychology, 57, 327-351. doi:10.1111/j.2044-8317.2004.tb00142.x

Havighurst, R. J. (1953/1961). Human development and education. New York, NY: Longmans, Green and Co.

Hirschi, A. (2011). Callings in career: A typological approach to essential and optional components. Journal of Vocational Behavior, 79, 60-73. doi:10.1016/j.jvb.2010.11.002

Hirschi, A., \& Herrmann, A. (2013). Calling and career preparation: Investigating developmental patterns and temporal precedence. Journal of Vocational Behavior, 83, 5160. doi:org/10.1016/j.jvb.2013.02.008

Hunter, I., Dik, B. J., \& Banning, J. H. (2010). College students' perceptions of calling in work and life: A qualitative analysis. Journal of Vocational Behavior, 76, 178-186. doi:10.1016/j.jvb.2009.10.008

Kanfer, R., Ackerman, P. L., \& Heggestad, E. D. (1996). Motivational skills and selfregulation for learning: A trait perspective. Learning and Individual Differences, 8, 185209. doi:10.1016/S1041-6080(96)90014-X

Kanfer, R., \& Heggestad, E. D. (1997). Motivational traits and skills: A person-centred approach to work motivation. In L. L. Cummings \& B. M. Staw (Eds.), Research in organizational behavior (Vol. 19). London, UK: Jai Press Inc. 
Karoly, P. (1993). Mechanisms of self-regulation: A systems view. Annual Review of Psychology, 44, 23-52. doi:10.1146/annurev.ps.44.020193.000323

Kuhl, J. (1985). Volitional mediators of cognition-behavior consistency: Self-regulatory processes and action versus state orientation. In J. Kuhl \& J. Beckman (Eds.), Action control: From cognition to behavior (pp. 101-128). New York, NY: Springer-Verlag.

Kuhl, J., Kazen, M., \& Koole, S. L. (2006). Putting self-regulation theory into practice: A user's manual. Applied Psychology: An International Review, 55, 408-418. doi:10.1111/j.1464-0597.2006.00260.x

Landis, R. S., Beal, D. J., \& Tesluck, P. E. (2000). A comparison of approaches to forming composite measures in structural equation models. Organizational Research Methods, 3, 186-207. doi:10.1177/109442810032003

Latham, G. P., Borgogni, L., \& Petita, L. (2008). Goal setting and performance management in the public sector. International Public Management Journal, 11, 385-403. doi:10.1080/10967490802491087

Lent, R. W., Brown, S. D., \& Hackett, G. (1994). Toward a unifying social cognitive theory of career and academic interest, choice, and performance. Journal of Vocational Behavior, 45, 79-122. doi:10.1006/jvbe.1994.1027

Locke, E. A., \& Latham, G. P. (1990). A theory of goal setting and task performance. Englewood Cliffs, NJ: Prentice Hall.

Locke, E. A., \& Latham, G. P. (2006). New directions in goal-setting theory. Current Directions in Psychological Science, 15, 265-268. doi:10.1111/j.1467-8721.2006.00449.x Park, N. (2004). The role of subjective well-being in positive youth development. The Annals of the American Academy of Political and Social Science, 591, 25-39. doi:10.1177/0002716203260078

Perkins, C. (2012). Student goal pursuit style and perceivable employability. Unpublished 
manuscript. Griffith University, Gold Coast, Australia.

Praskova, A, Creed, P. A., Hood, M. (in press). The development and initial validation of a career calling scale for emerging adults. Journal of Career Assessment.

Preacher, K., \& Hayes, A. (2008). Asymptotic and resampling strategies for assessing and comparing indirect effects in multiple mediator models. Behavior Research Methods, 40, 879-891. doi:10.1177/1069072707305763

Rapee, R. M., Craske, M. G., Brown, T. A., \& Barlow, D. H. (1996). Measurement of perceived control over anxiety-related events. Behavior Therapy, 27, 279-293. doi:10.1016/s0005-7894(96)80018-9

Rosso, B. D., Dekas, K. H., \& Wrzesniewski, A. (2010). On the meaning of work: A theoretical integration and review. Research in Organizational Behavior, 30, 91-127. doi:10.1016/j.riob.2010.09.001

Rothwell, A., \& Arnold, J. (2007). Self-perceived employability: Development and validation of a scale. Personnel Review, 36, 23-41. doi:10.1108/00483480710716704

Rothwell, A., Herbert, I., \& Rothwell, F. (2008). Self-perceived employability: Construction and initial validation of a scale for university students. Journal of Vocational Behavior, 73, 1-12. doi:10.1016/j.jvb.2007.12.001

Savickas, M. L. (1999). The transition from school to work: A developmental perspective. Career Development Quarterly, 47, 326-336. Retrieved from http://search.proquest.com

Seijts, G. H., Latham, G. P., Tasa, K., \& Brandon, W. L. (2004). Goal setting and goal orientation: An integration of two different yet related literatures. The Academy of Management Journal, 47, 227-239. doi:10.2307/20159574

Shulman, S., Feldman, B., Blatt, S. J., Cohen, O., \& Mahler, A. (2005). Emerging adulthood age-related tasks and underlying self processes. Journal of Adolescent Research, 20, 577603. doi:10.1177/0743558405274913 
Shulman, S., \& Nurmi, J.-E. (2010). Dynamics of goal pursuit and personality make-up among emerging adults. In S. Shulman \& J.-E. Nurmi (Eds.), The role of goals in navigating individual lives during emerging adulthood (pp. 57-70). San Francisco: Wiley.

Steger, M. F., Pickering, N. K., Shin, J. Y., \& Dik, B. J. (2010). Calling in work: Secular or sacred? Journal of Career Assessment, 18, 82-96. doi:10.1177/1069072709350905

Tofighi, D. \& MacKinnon, D. P. (2011). RMediation: An R package for mediation analysis confidence intervals. Behavior Research Methods, 43, 692-700. doi:10.3758/s13428-0110076-X

Tryon, R. A., \& Radzin, A. (1972). Purpose-in-life as a function of ego resiliency, dogmatism, and biographical variables. Journal of Clinical Psychology, 28, 544-545. doi:10.1002/1097-4679(197210)28:4<544::AID-JCLP2270280428>3.0.CO;2-2

Vallerand, R. J., Blanchard, C., Mageau, G. A., Koestner, R., Ratelle, C., Leonard, M., \& Gagne, M. (2003). Les passions de l'ame: On obsessive and harmonious passion. Journal of Personality and Social Psychology, 85, 756-767. doi:10.1037/0022-3514.85.4.756 van der Heijden, B. (2002). Prerequisites to guarantee life-long employability. Personel Review, 31, 44-61. doi:10.1108/00483480210412418

Weiss, J. W., Skelley, M. F., Haughey, J. C., \& Hall, D. T. (2004). Calling, new careers and spirituality: A reflective perspective for organizational leaders and professionals. Research in Ethical Issues in Organizations, 5, 175-201. doi:10.1016/S1529-2096(03)05009-0

Wittekind, A., Raeder, S., \& Grote, G. (2010). A longitudinal study of determinants of perceived employability. Journal of Organizational Behavior, 31, 566-586. doi:10.1002/job.646

Wrzesniewski, A. (2012). Callings. In K. S. Cameron \& G. M. Spreitzer (Eds.), The Oxford handbook of positive organizational scholarship. Oxford, UK: Oxford University Press. 


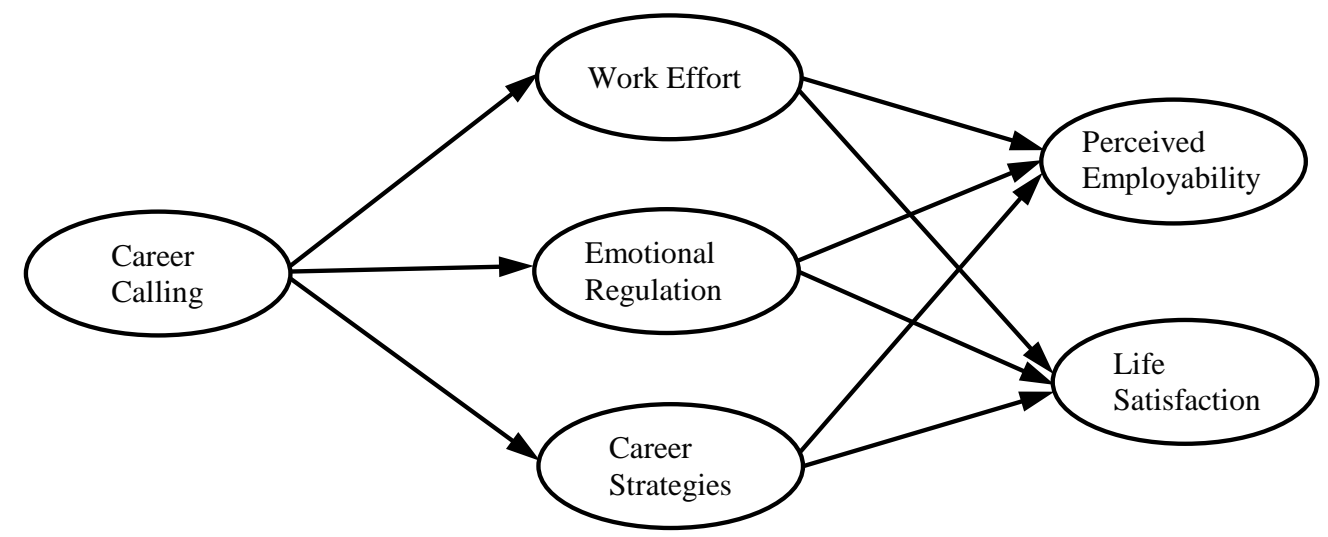

Figure 1. Hypothesised mediation model 




Figure 2. Final structural model with the non-significant path (career strategies $\rightarrow$ life satisfaction) removed. Standardised beta coefficients are reported. The dotted lines represent direct paths and coefficients from career calling to outcome variables. Coefficients in itallics represent direct effects in the presence of the mediators. Unless indicated, all paths are significant at $p<.001$. $* *$ Significant at $p<.01$ 